\title{
OLD TESTAMENT THEOLOGY AND THE CANON ${ }^{1}$
}

\author{
John Goldingay
}

\begin{abstract}
Summary
The article argues that Old Testament theology considers the insight that emerges from the form of the Old Testament canon, that it focuses on the canon of the Old Testament itself not the history of Israel, that it lets the canon itself be the canon, that it nevertheless recognises a canon within the canon, that it treats the first part of the twofold canon as of significance in its own right, but that it expects to find that the two parts of this canon illumine each other.
\end{abstract}

\section{Introduction}

My title is somewhat tautologous; by definition, the Old Testament is a canon, so Old Testament theology is bound to be canon-related. Yet the way we speak about Old Testament theology and about the canon indicates that actually the interrelationship of Old Testament theology and the canon can be quite complex.

We owe to Brevard Childs an emphasis on the juxtaposition of the two expressions ${ }^{2}$ though I find helpful Paul House's definition of 'canonical' in terms of 'analysis that is God-centered, intertextually oriented, authority-conscious, historically sensitive and devoted to the pursuit of the wholeness of the Old Testament message' ${ }^{3}$ And I find helpful William Abraham's emphasis that in origin 'canon' designates scripture not as a rule or a criterion for truth but as a means of grace, something designed 'to bring people to salvation, to make people holy,

1 The Institute for Biblical Research Annual Lecture, 2007, slightly revised.

2 See, e.g., Brevard Childs, Old Testament Theology in a Canonical Context (London: SCM, 1985/ Philadelphia: Fortress, 1986): 6-16.

3 Paul House, Old Testament Theology (Downers Grove, IL: IVP, 1998): 57. 
to make proficient disciples of Jesus Christ, and the like' (cf. 2 Tim. $3: 16) .{ }^{4}$ As canon, scripture is a norm, but it is first a resource. ${ }^{5}$ It is formative as well as normative (Moshe Halbertal). ${ }^{6}$

I have six comments to make on the interrelationship of Old Testament theology and the canon.

\section{Old Testament Theology Considers the Insight that Emerges from the Form of the Old Testament Canon}

Old Testament theology takes account of the form of the canon. There are at least three senses in which it might do so. One of Childs's theses is that the individual books of the Old Testament have been 'shaped to function as canon'.7 His examples vary in forcefulness. Perhaps paradoxically, they are particularly illuminating in connection with the poetic books, Psalms, Proverbs, Ecclesiastes, and the Song of Songs. But whether or not the books are so shaped, Childs is surely right that we should do Old Testament theology on the basis of the books' canonical form rather than on the basis of historical and redactioncritical hypotheses about their origins, such as the tradition that Genesis was written by Moses or the hypothesis that it was written by a committee in the Second Temple period. If we 'seek to give theological autonomy to a reconstructed Yahwist source' we disregard the work of the people who made it part of the Torah and accepted it in this form as scripture. ${ }^{8}$ Admittedly, there are historical and redaction-critical hypotheses for which the canonical text gives us significant evidence, such as the link between the book called Isaiah and both the period of

4 William Abraham, Canon and Criterion in Christian Theology (Oxford/New York: OUP, 1998): 51. He notes that feminist theology has actually and surprisingly turned the canon back into 'a means of healing and transformation' rather than a criterion (460), though of course it has also rejected it as a criterion or norm.

5 Cf. John Goldingay, Models for Scripture (repr. Toronto: Clements, 2004): 196-97.

6 Moshe Halbertal, People of the Book (Cambridge, MA/London: Harvard UP, 1997): 3. Benjamin D. Sommer, indeed, comments that in Judaism the scriptures-and even the Mishnah and Gemaras - are formative rather than normative; it is subsequent tradition that is directly normative for behaviour (Benjamin D. Sommer, 'Unity and Plurality in Jewish Canons' in One Scripture or Many?, ed. Christine Helmer and Christof Landmesser [Oxford/New York: OUP, 2004]: 108-50 [128-30]).

7 See Brevard Childs, Introduction to the Old Testament as Scripture (London: SCM/Philadelphia: Fortress, 1979).

8 Childs, Old Testament Theology in a Canonical Context: 11. 
Isaiah ben Amoz and that of Cyrus the Persian (Isa. $1: 1 ; 45: 1$ ), ${ }^{9}$ and it is appropriate to take this into account in doing Old Testament theology.

It can also be enlightening to consider the theological implications of the ordering of the books in the canon. Both Jack Miles and Stephen Dempster, for instance, look at the Hebrew-Aramaic canon as if it is a narrative. ${ }^{10}$ Yet this is a construct they bring to the text. While the scriptures are dominated and framed by narrative, they are not actually a narrative. Both authors thus have to do considerable linking of dots, and come to monumentally different conclusions regarding the dynamics of the alleged narrative: Miles sees it as relating God's gradual withdrawal, Dempster as a story that moves from Adam to David and a coming Davidic king. Less inference is involved in Marvin A. Sweeney's account of the canon as implying 'the initiation of Jewish life based on the Torah, its disruption in the period of the monarchy and the Babylonian exile, and its restoration in the aftermath of the exile', ${ }^{11}$ or in Hans Walter Wolff's non-narrative view of the Greek canon as moving from past to present to future. ${ }^{12}$ Or (to adapt a formulation by Walter Brueggemann) one might see this threefold canon as suggesting the definition of the community's nature in story and command, then in the discernment of the sure ordering of created reality, then in the irruption of something new in uncredentialed channels. ${ }^{13}$ (I do not think we have to choose between the Hebrew-

9 I thus find it strange that Childs argues that reference to the exilic context of Isa. 40-55 has been almost entirely removed from these chapters (Introduction to the OT as Scripture: 325$)$.

10 Jack Miles, God: A Biography (New York/London: Simon and Schuster, 1995); Stephen Dempster, Dominion and Dynasty (Leicester, UK/Downers Grove, IL: IVP, 2003). With Miles may be compared Richard E. Friedman, The Disappearance of God (Boston: Little, Brown, 1995), reissued as The Hidden Face of God (San Francisco: Harper, 1996).

11 'Tanak versus Old Testament' in Problems in Biblical Theology, ed. Henry T. C. Sun and others (Rolf Knierim Festschrift; Grand Rapids: Eerdmans, 1997): 353-72.

12 Hans Walter Wolff, The Old Testament (Philadelphia: Fortress, 1973/London: SPCK, 1974).

13 Walter Brueggemann, The Creative Word (Philadelphia: Fortress, 1982). Brueggemann applies this formulation to the Hebrew-Aramaic canon, but I think it fits the Greek canon better. Brueggemann interestingly observes (11) that conservative persons will be inclined to focus on the Torah, radicals on the Prophets, and people such as humanistic psychologists on the Writings. At Fuller Theological Seminary, the MDiv requires a course in the Torah (students may study both Prophets and Writings, but must do only one), while courses in the School of Psychology require a course in the Writings (students may study both Torah and Prophets but are not required to do so). 
Aramaic and Greek ordering of the books; ${ }^{14}$ while the former was adopted by the synagogue and the latter by the church, both may be of Jewish origin. We do have to choose between the Hebrew-Aramaic list of books and the Greek one, and I choose the Hebrew-Aramaic one, though I do not think it makes a whole lot of difference except-as someone observed-for increasing the amount of the Old Testament that the church ignores.)

But more important than the shaping of individual books or their order is the rhetorical form of the canon. It is indeed dominated by narrative, in which Israel tells its story, twice, in large-scale versions that dominate the first half of the Greek Bible and that bookend and frame the Hebrew-Aramaic Bible. But then, narrative is not all, but incorporates and is accompanied by substantial speech of address, speech in which God or God's representatives address Israel, with narrative statements having a place but not dominating. And further, the canon also incorporates and is complemented by speech in which human beings address YHWH in praise, protest, and penitence. ${ }^{15}$ One might indeed argue that the Hebrew-Aramaic Bible comprises a stepped structure, narrative-address-prayer-address-narrative.

The canon's being dominated by narrative signifies for Old Testament theology that Israel's faith is a gospel, a story declaring good news about what God has done. It is not fundamentally a series of present-tense statements such as 'God is love' nor a series of imperatives such as 'love your neighbour' but a series of past-tense statements such as 'God so loved the world that he gave...' Old Testament theology is thus first an explication of the acts of God. In fact, the much-derided biblical theology movement was not so wrong. ${ }^{16}$ These narratives are not just one collection of liberating

14 As Brevard Childs argues in Biblical Theology in Crisis (Philadelphia: Westminster, 1970): 109.

15 Claus Westermann (Elements of Old Testament Theology [Atlanta: Knox, 1982]: 10) sees the Hebrew-Aramaic canon as following the sequence narrative-addressresponse; cf. Rolf Rendtorff's comment, 'In the first part of the canon God acts, in the second God speaks, and in the third part of the canon people speak to God and of God' (The Canonical Hebrew Bible [Leiden: Deo, 2005]: 6). But this rather oversimplifies the Writings.

16 In fact, I wonder if the biblical theology movement is due for reevaluation. By some quasi-Hegelian logic it is customary for fashions in theology to be despised in their aftermath, then to undergo rehabilitation (it happened to Barth). The biblical theology movement had its weaknesses and its blind spots but it had its insights and strengths. 
stories and traditions, parallel to other such collections from other cultures. They tell us the good news about what God did for Israel in setting about to bless the world. And their narrative form is intrinsic to their theological statement. If their gospel is true, it cannot be expressed in the form of traditional systematic theology.

The dominance of narrative in the Old Testament canon also makes it possible to discuss complex theological questions that are not open to being 'solved' in the form of the discursive, analytical statement that came to dominate theology. Narrative makes it possible to discuss the relationship between divine sovereignty and human freewill (in Exod. 5-14) or the nature of the presence of God or the way God deals with the sin of the people of God (in Exod. 32-34) or the relationship between fulfilment and non-fulfilment and between obedience and disobedience on the part of the people of God (in Joshua) or the relationship between divine politics and human politics (in 2 Kings).

So it is theologically significant that narrative opens the Old Testament and dominates it. But it is also theologically significant that these narratives both incorporate substantial instruction in nonnarrative form (in the Torah) and are accompanied by further substantial non-narrative instruction (in the Prophets). ${ }^{17}$ Narrative is not everything. Indeed, there is a dialectical conversation between narrative and instruction. In the Torah, the conversation is symbolised by the enfolding of instruction into the narrative; in the Prophets, it is symbolised by their reference back to the narrative events. The First Testament toggles narrative and precept. ${ }^{18}$

So the narrative pauses to make theological statements about who God is, such as the outline Old Testament systematic theology in Exodus 34:6-7 where YHWH offers a self-description in terms of character traits. This non-narrative description of YHWH implicitly constitutes a theological reflection on the narrative that precedes, though in itself it constitutes a statement of who YHWH simply is. Likewise Leviticus 19:18 requires that Israelites love their neighbours, especially the ones who have wronged them. The immediate basis for this is the fact that 'I am YHWH,' that people are to revere YHWH, that

17 Brian Brock, Singing the Ethos of God (Grand Rapids/Cambridge: Eerdmans, 2007): 33, notes that it is also ethically significant.

18 I derive this image from Deirdre N. McCloskey, The Bourgeois Virtues (Chicago/London: University of Chicago, 2006): 272, who in turn credits it to Richard A. Lanham, The Electronic Word (Chicago: University of Chicago, 1993): 79ff. 
TYNDALE BULLETIN 59.1 (2008)

they are to observe YHWH's laws, and in the slightly wider context that 'you are to be holy because I, YHWH your God, am holy' (Lev. 19:2). In a much looser sense, such teaching also links with the narrative, but it stands as a statement of who YHWH is and what people are supposed to do that is independent of such contexts. And the teaching in the Prophets and Wisdom Books majors on such statements.

The canonical form of the Old Testament thus does point theology towards accompanying narrative statements such as 'God so loved the world...' with statements such as 'God is love' and statements such as 'you are to love people who wrong you.'

Then as well as narrative and teaching, the Old Testament incorporates substantial material in which people speak to God in praise, protest, and penitence. Again this material links closely with narrative and instruction, which often include praise, protest, and penitence; indeed one might see the narratives as a whole as praise, prayer or protest. ${ }^{19}$ Conversely, psalms and other prayers often take narrative form, while the Psalter is formally constructed as a book of instruction. But these psalms and prayers show that narrative and instruction are properly turned into explicit praise, prayer, and penitence; theology and ethics become doxology. And they show teaching on praise, prayer, and penitence taking the form of instances of praise, prayer, and penitence.

\section{Old Testament Theology Focuses on the Canon of the Old Testament Itself, Not the History of Israel}

Second, Old Testament theology's relationship with the canon means it focuses on the text of the Old Testament, not the history to which it refers. As Childs put it, "the object of theological reflection is the canonical writing of the Old Testament... not the events or experiences behind the text' and not these events or experiences apart from their 'construal in scripture by a community of faith and practice'. ${ }^{20}$

19 Gerhard von Rad called the Books of Kings a Gerichtsdoxologie, an act of praise at the justice of God's judgment (Gerhard von Rad, Old Testament Theology [Edinburgh: Oliver and Boyd/New York: Harper, 1962]: 1:343; cf. Gerhard von Rad, 'Gerichtsdoxologie' in Gesammelte Studien zum Alten Testament [Munich: Kaiser, 1973]: 2:245-54).

20 Childs, OT Theology in a Canonical Context: 6 . I have paraphrased the middle part of the quotation to clarify the way I understand Childs's words. 
Nevertheless he goes on to make explicit that the scriptural story needs to refer to things that actually happened. To adapt a statement by James Barr, it is no good the exodus happening canonically but not in the world outside the canon. ${ }^{21}$

Genesis to Joshua declares that God created, God started over, God promised, God delivered, God sealed, and God gave. ${ }^{22}$ But did God do these things? Much Old Testament scholarship sees virtually no historical value in Genesis to Joshua. If it is right, this fatally imperils the validity of that series of theological statements. An Old Testament narrative theology is dependent on the factuality of the events it refers to. One can perhaps make definitional statements such as God is faithful and merciful without these being dependent on particular events, and one can engage in narrative theological discussion of issues such as the relationship between divine sovereignty and human freewill without the narrative being historical. One can hardly make past tense, gospel statements such as God promised and God delivered, without these being dependent on a relationship with particular events. If God did not make promises to Israel's ancestors or deliver Israelites from Egypt, it might still be true that YHWH is a God who promises and a God who delivers, but the major content of and grounds for making those statements has disappeared. Further, the Old Testament builds further declarations in the realms of theology, ethics, and spirituality on YHWH's having made these particular promises (of land, peoplehood, and blessing) and having effected this particular deliverance (from serfdom in Egypt) (e.g. Exod. 23:9; Deut. 26:1-14). Reckoning that Genesis to Joshua is pure fiction does not disprove its theology, ethics, and spirituality, but it does remove much of its substance as well as the basis on which the Old Testament commends it.

So the basic historicity of the events related in the Old Testament is important to the validity of its theology, and this is one reason why the study of Israelite history deserves investigation. This does not mean that our actual recognition of the Old Testament's truth and its theology is dependent on this investigation. There is a difference here

21 See James Barr, 'Childs' Introduction to the Old Testament as Scripture', Journal for the Study of the OT 12 (1980): 12-23 (21).

22 Cf. John Goldingay, Old Testament Theology Volume One (Downers Grove, IL: IVP, 2003/Carlisle: Paternoster, 2006). This paper includes one or two sentences adapted from this volume and from John Goldingay, Old Testament Theology Volume Two (Downers Grove, IL: IVP/Carlisle: Paternoster, 2006), as well as a longer section from the third volume of this work which I hope will appear in 2009. 
between Old Testament and New Testament study, where the nature of the Gospel narratives (specifically their date) makes it reasonable to treat them as good historical sources for an understanding of who Jesus was and what he did, an understanding that does not have to presuppose their acceptance as scripture. ${ }^{23}$ The nature of the books from Genesis to Joshua and the state of archaeological investigations of the period they cover make it impossible on purely critical grounds to treat the books as good historical sources. One can make a case for the reasonable plausibility of their being that, but not for the overwhelming probability of it. My conviction that they have enough historical value to justify the theology that is built on them does not come from critical study alone but from trust in Christ himself, from whom I receive these scriptures.

The basic historicity of the Old Testament story is important to the validity of its theology. (I do not know how much historicity is enough, but I know God does, and has looked after the matter.) But it does not follow that the investigation of Old Testament history is part of doing Old Testament theology. The subject matter for Old Testament theology is the canonical writings. Insofar as 'God created' is a summary of a significant Old Testament truth, it is Job, Proverbs, the Psalms, Genesis 1-2, and other Old Testament descriptions of God's creating the world, that spell out that statement. Empirical scientific investigation of the process whereby the world came into being could lead to theologically significant results, but these would not be part of 'Old Testament theology'. Likewise, investigating the actual history of Israel's ancestors or the exodus could lead to theologically significant results, but these would not be part of 'Old Testament theology'. The study of Israelite history is an ancillary and supportive discipline like the study of philosophy.

Hans Frei traced the fateful process whereby eighteenth-century scholarship came to a new realisation of the difference between the story the scriptures tell and the actual history of Old and New Testament times. It then had to make a fateful decision about whether to be theologically interested in the history or the story. ${ }^{24}$ There was no contest; history had become God by the eighteenth century, so only history could have the status of a revelation of God. Thus forty or fifty

\footnotetext{
23 See recently Richard Bauckham, Jesus and the Eyewitnesses (Grand Rapids: Eerdmans, 2006).

24 Hans Frei, The Eclipse of Biblical Narrative (New Haven: Yale UP, 1974).
} 
years ago when I started studying the Old Testament, one could take it for granted that John Bright's History of Israel ${ }^{25}$ was a one-stop guide to the Old Testament. But it is clearer now that, after scholarship has focused for two centuries on the quest for the historical Israel, it has made no significant progress, and never will. Whereas it was inevitable that scholarship made that choice two centuries ago, it was the wrong choice. This is so from a purely practical viewpoint. The history of Israel exists, but we apparently have no access to it, so we can hardly make it the locus of theological investigation. ${ }^{26}$ But what God has actually given us as canon is some texts, which at least do have the virtue of being accessible. The subject for Old Testament theology is the Old Testament, not the history of Israel. At this point, too, the biblical theology movement was not so wrong.

\section{Old Testament Theology Lets the Canon Itself Be the Canon}

Third, recognising the Old Testament as canon means Old Testament theology is wary of reading the scriptures in light of the creeds, the rule of the faith, the church's theological tradition, the church's exegetical tradition, and the insights of our own age. It lets the canon itself be the canon.

The trouble with the scriptures, theologians such as Irenaeus recognised, is that by collecting isolated verses from here and there, one can prove anything. Today we might say individual verses must be interpreted in light of their literary context and their author's intention. Irenaeus's equivalent safeguard is to measure the interpretation of individual verses by 'the rule of the faith'. ${ }^{27} \mathrm{He}$ notes that we receive this rule at our baptism, which points to the link between the rule of the faith and the creed. The creed with its summary of the biblical story in terms of the activity of Father, Son, and Spirit is an expression of the rule of the faith. Subsequent Christian faith has often operated with a

25 John Bright, History of Israel (Philadelphia: Westminster/London: SCM, 1959).

26 Which is one aspect of or reason for what Leo G. Perdue calls 'the collapse of history' (The Collapse of History: Reconstructing Old Testament Theology [Minneapolis: Fortress, 1994]; Reconstructing Old Testament Theology after the Collapse of History [Minneapolis: Fortress, 2005]).

27 The kanōn of the faith, in fact (the translation 'the rule of faith' gives a misleading impression). See, e.g., Irenaeus, Against Heresies I: 9.4 
related outline understanding of the Christian story in terms of creation, fall, Christ's coming, and the final judgment.

As frameworks for interpreting scripture these comprehensively marginalise most of the Old Testament after Genesis 3 and comprehensively skew biblical theology. Old Testament theology cannot do justice to the canon if it follows the creed or the rule of the faith. I do not imply that the rule of the faith and the creed lack contextual and intrinsic merits; I say the creed every Sunday. But it is not the case that 'the church's Rule of Faith constrains the theological teaching of a biblical text. ${ }^{28}$ The rule of the faith offers guidance to theological interpretation, but in the final analysis only the biblical text itself constrains its theological teaching.

Similar considerations apply to the church's broader theological tradition. B. B. Warfield defined biblical theology as 'the task of coordinating the scattered results of continuous exegesis into a concatenated whole, whether with reference to a single book of Scripture or to a body of related books or to the whole Scriptural fabric'. ${ }^{29}$ Systematic theology's task is then to order the material in terms of its own categories. This vision might have the capacity to rescue Old Testament theology or biblical theology from unconscious assimilation to the categories of systematics. ${ }^{30}$ One distinction between

28 So Robert W. Wall, 'Reading the Bible from within Our Traditions: The "Rule of Faith" in Theological Hermeneutics' in Between Two Horizons, ed. Joel B. Green and Max Turner (Grand Rapids: Eerdmans, 2000): 88-107 (90).

29 B. B. Warfield, 'The Idea of Systematic Theology', Presbyterian and Reformed Review 7 (1896): 243-71 (256). Abraham comments, 'this is a preposterous undertaking.... One would have to be virtually omniscient' (William Abraham, Canon and Criterion in Christian Theology: 326). He would presumably react in a similar way to Norman Gottwald's declaration that 'a proper beginning point for a theology of the Hebrew Bible is to take account of everything that the Bible says about God, everything that God says, and everything that people say to God. This would be to follow radically and faithfully the course of the text.... Unless and until this is done,... theological criticism will continue to build very selectively on narrow bases of Godtalk' ('Literary Criticism of the Hebrew Bible' in Mappings of the Biblical Terrain, ed. Vincent L. Tollers and John Maier [Lewisburg, PA: Bucknell UP/London: Associated University Presses, 1990]: 27-44 [see 39]). Gottwald himself later acknowledged that this was a task of some magnitude ('Rhetorical, Historical, and Ontological Counterpoints in Doing Old Testament Theology' in God in the Fray, ed. Tod Linafelt and Timothy K. Beal [W. Brueggemann Festschrift; Minneapolis: Fortress, 1998]: 1123 [see 12]).

30 Contrast the way the opening chapters of Childs's OT Theology in a Canonical Context emphasise the notion of revelation, not really facing the implications of the fact that revelation is a relatively modern construct related to a relatively modern philosophical question, and not a biblical category. 
biblical theology and systematics is the conscious way systematics expresses itself in terms of the philosophical questions of its day, and Old Testament theology needs to be aware of the interplay between systematics and philosophy. Both classical theism and open theism, for instance, have difficulty doing justice to aspects of the Old Testament (God must always know the future because God is omniscient; God cannot know the future at all because the future is unknowable). Old Testament theology works with the canon rather than with the church's theological convictions. Francis Watson comments that 'theology may itself constitute a hermeneutic.' ${ }^{31}$ Insofar as this means the church's doctrinal tradition helps one to see things in scripture, this is a positive notion. But like any hermeneutic, it functions properly when it is then subordinate to the text.

The link between Old Testament theology and the canon implies paying attention to the whole Old Testament. A famous shortcoming of the biblical theology movement was its neglect of the wisdom literature, a corollary of its stress on God's acts in history. Both neglect and stress reflected the theological, philosophical, historical, and cultural circumstances of the mid-twentieth century in the West. The subsequent reaction that has led to 'a temptation to pan-creationism (like an earlier pan-covenantalism)' 32 also reflects theological, philosophical, historical, and cultural circumstances, along with the necessity for scholars to have something to say that differs from what the previous generation said, and for publishers to have something different to sell. The appropriate response is to acknowledge the culture-relative nature of all our work and pay special attention to theological work issuing from other contexts that may broaden our horizons and enable us to do better justice to the canon as a whole.

In seeking to develop a new biblical theology, Childs indeed urged the recovery of the church's exegetical tradition. ${ }^{33}$ By and large and for similar reasons, what is true about the creed is true of this exegetical tradition as expressed in the work of great commentators such as

31 Francis Watson, Text and Truth (Grand Rapids: Eerdmans, 1997): 241.

32 Walter Brueggemann, 'Jeremiah: Creatio in Extremis' in God Who Creates, ed. William P. Brown and S. Dean McBride (W. S. Towner Festschrift; Grand Rapids: Eerdmans, 2000): 152-70 (153). Cf. Rolf P. Knierim, 'On the Subject of War in the Old Testament and Biblical Theology' in Reading the Hebrew Bible for a New Millennium, ed. Wonil Kim and others (Harrisburg, PA: Trinity, 2000): 1:73-88 (see 79).

33 See Childs, Biblical Theology in Crisis: 139-47. 
Origen, Augustine, and Luther. The consistency of their Christological interpretation means they fairly consistently ignore the Old Testament's inherent meaning. But there is one connection in which such a recovery is desirable. Premodern commentators knew they were studying documents that were designed to be a resource or a means of grace, ones that made statements about God not merely about Israel's faith. For these commentators, writing a commentary and preaching a sermon were not such different enterprises. Modern commentaries are short on sentences beginning with the word 'God', or even containing it. Old Testament theology studies the faith of the Old Testament not the faith of Israel, and it studies the one in whom Israel had faith (or was supposed to have faith) not merely the faith statements that Israel made. Ada María Isasi-Díaz comments on Psalm 137, 'for us Christians, the important thing regarding this psalm, and all of the Bible, is that it gives voice to an authentic faith-experience.' 34 Rather, the important thing about the Bible is what it says about God.

In origin, biblical criticism urged a critical stance with regard to traditional assumptions about scriptural interpretation and traditional uses of scripture, and this continues to be a necessity if we are to let the canon be the canon. Feminist criticism offers an example as it has raised questions about traditional interpretation of Genesis 1-3 and about books such as Ruth and the Song of Songs. Postcolonial interpretation has exposed the unbalanced way Old Testament theology made much of the exodus without facing the theological and ethical issues raised by the Israelite occupation of Canaan. Again, the Old Testament sets some openness to other cultures alongside its insistence on the decisive importance of what YHWH was doing in Israel, but in the modern missionary movement, set in the context of the European nations carving out their empires, Christian faith was identified with Western culture, and the open aspect to the Old Testament's attitudes was ignored in favour of the exclusivist one. ${ }^{35}$

That does also show how modern readers, too, import their own categories into scripture, as do postmodern readers, and whereas criticism began by questioning the church's tradition of interpretation, it now must proceed by questioning criticism itself. Yet the modern

34 Ada María Isasi-Díaz, "By the Rivers of Babylon"” in Reading from This Place, ed. Fernando F. Segovia and Mary Ann Tolbert (Minneapolis: Fortress, 1995): 1:14963 (151).

35 Cf. Kwesi A. Dickson, Uncompleted Mission (Maryknoll, NY: Orbis, 1991). 
tradition's commitment to understanding what texts were communicating in their historical context does give it the potential of discovering some more of what the Holy Spirit was communicating through these texts when inspiring them. A potential of our postmodern context is the possibility of recovering the strength of the premodern tradition while holding onto the strength of the modern tradition, and letting each safeguard against the other's weakness. ${ }^{36}$

Musa Dube expresses approval of Christian readings of scripture that 'reject the privileging of biblical texts and religions above other cultural perceptions of reality'. ${ }^{37}$ Now that open stance taken by the Wisdom Literature to other peoples' learning provides a warrant for African, Asian, and Native American readers 'reading biblical stories together with their native ones'. But it is a different matter when this involves 'a refusal to accord the biblical text the final authority it claims for itself to suppress differences'. ${ }^{38}$ The issue is not whether there is insight in other cultures' stories, or whether reading in the context of another culture helps us identify what texts have seemed to say but do not actually say, or whether they have 'served imperializing nations'. It is that the texts 'propound imperializing ideology'. ${ }^{39}$ The Bible claims the authority to suppress differences; Dube refuses to grant it this authority, on the basis of the prior decision that colonial cultures and their stories and traditions have as much validity as imperial cultures and their cultures and traditions. YHWH's sole deity then becomes just one culture's perception. But thinking in terms of Old Testament theology and the canon implies assuming the Old Testament is right in affirming that YHWH alone is God and right in its understanding of God, and that we properly privilege the biblical narrative in relation to other cultural perceptions of reality because

36 Contrast Childs's implicit attitude, according to John Barton, that historical criticism has been 'one long bad dream' ('Canon in Old Testament Interpretation' in In Search of True Wisdom, ed. Edward Ball [R. E. Clements Festschrift; JSOTSup 300; Sheffield: Sheffield Academic, 1999]: $37-52$ [38]).

37 Musa Dube, Postcolonial Feminist Interpretation of the Bible (St Louis: Chalice, 2000): 195.

38 Dube, Postcolonial Feminist Interpretation of the Bible: 108.

39 Dube, Postcolonial Feminist Interpretation of the Bible: 108. As far as the Old Testament is concerned, I find this an odd claim. Only during David and Solomon's day is Israel anything like an imperial power. In the rest of the Old Testament story, Egypt, Canaan, Philistia, Assyria, Babylon, Persia, and Greece are the imperial powers and Israel is resisting them (or not). 
YHWH was indeed undertaking something in Israel that was of supreme significance for every culture.

\section{Old Testament Theology Recognises a Canon within the Canon}

So the canon is the canon; but (fourth) Old Testament theology recognises that there are canons within the canon.

There is something systematically ambiguous about talk of biblical criticism. It evaluates interpretations by the text itself to check whether they are actually imposed on the text, presupposing 'the principle of charity', the assumption that the text makes sense. ${ }^{40}$ But it comes to apply its critical principle to the text itself in light of our own (supposed) understanding of the real truth. Critical approaches work on the basis of having their principle of criticism, their canon, within themselves. Both modern and postmodern, both liberal and evangelical perspectives make themselves the criterion for truth. Readers recognise that the scriptures are time-conditioned or culture-relative but not that they are themselves time-conditioned and culture-relative.

In describing 'The Family in First Temple Israel', Joseph Blenkinsopp begins by noting that the biblical source material has the character of 'canonical texts'. He then infers (perhaps to one's surprise) that this means their stance was 'dictated by the agenda and ideology of those who put the collection together' ${ }^{41} \mathrm{He}$ is thus inclined to a suspicious reading of the Old Testament regulations about the family, and comments (for instance) on the ruling in Deuteronomy 22:23-29 about a woman who has been raped that 'the law's indifference to her interests in general is too clearly in evidence to require comment'. ${ }^{42}$

Whose interests do the regulations in the Torah serve? They are indeed sometimes open to a variety of interpretations in this connection, and thus to a variety of evaluations. The rules about stealing animals in Exodus 22:1-4 (21:37-22:3) can be read as in the

40 See Willard Van Orman Quine, Word and Object (Cambridge, MA: MIT, 1960): 59; cf. Halbertal, People of the Book: 27-28.

41 In Leo Perdue et al., Families in Ancient Israel (Louisville: WJK, 1997): 48-103 (see 49). Cf. J. G. McConville's comments in God and Earthly Power (LHB/OTS 454; London/New York: Clark, 2006): 3.

42 Perdue et al., Families in Ancient Israel: 63. 
favour of the rich or the poor. They might protect the rich and penalise the poor who 'borrow' and then cannot pay back; 'this regulation may have been an important source for slavery. ${ }^{43}$ But they might protect the poor from having anyone (including the rich) appropriating the animals that are crucial to their livelihood. Something similar is true about that ruling concerning rape. The point that is 'too clearly in evidence to require comment' for Blenkinsopp is not at all clear to the commentators on Deuteronomy; according to one of the most rigorously historical-critical of them, the regulation 'protects' the woman. ${ }^{44}$ But at the same time, it does also protect her father's interests, and it is common for regulations in the Torah to balance interests thus. It is the nature of law to incorporate such compromise.

Psalm 37 likewise can be read as a profound assertion of the status quo, a self-affirmation of the landed class, but it can also be read as an act of radical hope by the disenfranchised, who are confident that current unjust land distribution cannot endure, and that the land eventually will be reassigned to 'the righteous'. ${ }^{45}$ Qohelet can be read as reflecting the attitudes of the powerful and comfortable, or as a call to oppressed people 'to resist the fascinations of the dominant culture'. ${ }^{46}$

It is therefore appropriate to utilise a suspicious hermeneutic in reading the canonical writings and to ask whose interests they serve. Identifying with the fact that the Jewish and Christian communities gave them canonical status does not exclude a suspicious reading. Jesus models this in commenting on the regulation concerning divorce. Moses gave it, Jesus says, because of people's stubbornness. It does not correspond to the way God made humanity at the beginning (Mark 10:1-9). Within scripture, then, one can distinguish between God's will as it goes back to creation, and ways in which scripture's teaching allows for human waywardness. God did not merely reveal to Israel the

43 So Frank Crüsemann, The Torah (Minneapolis: Fortress/Edinburgh: Clark, 1996): 164.

44 A. D. H. Mayes, Deuteronomy (London: Oliphants, 1979/Grand Rapids: Eerdmans, 1981): 313.

45 Walter Brueggemann, The Book that Breathes New Life (Minneapolis: Fortress, 2005): 160. Cf. Walter Brueggemann, The Psalms and the Life of Faith (Minneapolis: Fortress, 1995): 235-57.

46 Jorge Pixley, 'Christian Biblical Theology and the Struggle against Oppression' in Jews, Christians, and the Theology of the Hebrew Scriptures, ed. Allis Ogden Bellis and Joel S. Kaminsky (Atlanta: SBL, 2000): 173-77 (175). 
ultimate divine standards and then leave Israel on its own when it failed to live up to them, with the result (for instance) that women who were thrown out by their husbands were left with no evidence of their status. ${ }^{47}$ Notwithstanding what was so from the beginning, marriages are going to break down, and in a patriarchal world women are going to suffer. God therefore inspires a regulation to protect them from some of the consequences of their husbands' behaviour.

The tension between how things were at the beginning and how things are when one makes allowance for human stubbornness runs through the Torah, and the rest of the scriptures. God's allowing for human stubbornness in the New Testament appears in its acceptance of Roman slavery, an institution that stands in much greater tension with how things were at the beginning than the temporary debt servitude of which the Old Testament speaks. In principle one can plot all the scriptures' instructions on an axis between how things were at the beginning and how they are in light of human stubbornness. God is always concerned to pull us towards realising the creation vision but is always starting where we are.

So there is a canon within the canon. This does not mean the outer canon ceases to be canon; we must not make the canon within the canon into the canon. ${ }^{48}$ The material that makes allowance for human stubbornness still has Moses' authority. It is still part of scripture that is useful for equipping the Christian community to do good work (2 Tim. $3: 16)$.

Crucially, the basis for identifying the canon within the canon comes from within the scriptures themselves, not from Jesus himself or from his culture. Blenkinsopp is sometimes explicit that his suspicious reading of scripture takes as its criterion the convictions of 'most modern readers'. ${ }^{49}$ Recognising the canonical status of the scriptures opens up the possibility of learning things that can help refine and broaden our attitudes as people who are so limited through being modern readers. Questions about ideology that generate a suspicious interpretation can coexist with a consensual interpretation that assumes

\footnotetext{
47 The matter is one of continuing significance for the Jewish community: see, e.g., Judith Plaskow, The Coming of Lilith (Boston: Beacon, 2005): 147-51.

48 I. Lönning, 'Kanon im Kanon' (Oslo: Universitets Forlaget, 1972): 271; cf. Goldingay, Models for Interpretation of Scripture (reprinted Toronto: Clements, 2004): 106.

49 E.g. Perdue et al., Families in Ancient Israel: 84.
} 
the community was right to accept these texts into its scriptures. That may also make it appropriate to prefer interpretations that cohere with this assumption. ${ }^{50} \mathrm{~A}$ critical stance is finally subordinate to a consensual, compliant stance. Paradoxically, that is more likely to achieve one of the stated aims of ideological interpretation, which is that interpretation should be ethical. ${ }^{51}$ If we assume ahead of time that our perspective as modern people is right, and evaluate the scriptures in light of it, this inhibits us from changing or becoming more ethical. If we assume that the scriptures have a positive ethical contribution to make to our understanding and lives, this opens us to change and ethical development.

Old Testament theology recognises canons within the canon, but does not let them become the canon.

\section{Old Testament Theology Treats the First Part of the Canon as Significant in Its Own Right}

Fifth, Old Testament theology treats the first part of the canon as significant in its own right. It does not reinterpret or reevaluate its theological insights in light of the New Testament. Specifically, it does not reinterpret Old Testament texts in light of the way the New Testament uses them. The New Testament's use of Old Testament texts has no necessary significance for what Old Testament theology does with these texts.

As the psalm most often quoted in the New Testament, Psalm 110 provides an example. ${ }^{52}$ In light of the New Testament use of the psalm, traditional Christian exegesis took it as a messianic prophecy that Jesus fulfilled. ${ }^{53}$ Interpreters now more commonly justify this understanding on the basis of the psalm's having come to be interpreted messianically

50 Contrast Itumeleng Mosala's observation, 'traditionally the biblical texts that condemn or demand relief from debt and indeed slavery are generously appraised by the readers of the texts' ('The Politics of Debt and the Liberation of the Scriptures,' in Tracking The Tribes of Yahweh, ed. Roland Boer [JSOTSup 351; London/New York: Sheffield Academic, 2002]: 77-84 [80]). This is apparently a bad thing.

51 See. e.g., Elizabeth Schüssler Fiorenza, 'The Ethics of Interpretation', JBL 107 (1988): 3-17.

52 The paragraphs that follow utilise material in my Psalms 90-150 (forthcoming Grand Rapids: Baker, 2008).

53 Derek Kidner continues to argue trenchantly for this understanding (Psalms 73-150 [London: IVP, 1975]: 391-92). 
in Second Temple Judaism. One would never guess the messianic interpretation from the psalm itself; it can only be read into it.

That also applies to a current 'canonical' approach to the Psalter, which argues that in the context of the Psalter itself, which reached its canonical form in the Second Temple period when Israel had no kings, the psalms about the Israelite king would already be understood messianically. While it is the case that some people who used these psalms could have understood them messianically, this is by no means the only option in the Second Temple period. People who were familiar with Isaiah 55:3-5, for instance, a passage that itself reworks phrases from Psalm 89, could reckon that psalms about the king now apply to the whole people. The pre-exilic kings are also important in the Second Temple narrative of Chronicles, and there is no indication that this is a messianically-inclined work. If Chronicles or the Psalter were a messianically-inclined work, one would expect some concrete indication of this, but there is none, despite the fact that in other respects the Psalter shows much reworking of earlier psalms and psalm-like material (as Chronicles does in relation to Kings). We know from the Psalms of Solomon that Second Temple times produced messianic psalms, but the canonical Psalter does not contain any.

When YHWH spoke the words in Psalm 110 in Old Testament times, people could not have been expected to understand them as the New Testament does. ${ }^{54}$ The relationship between New Testament and Old Testament text is then the one that often obtains. In light of Jesus' coming, the Holy Spirit inspires people to see significance in the Old Testament that was not there before.

J. L. Mays, for instance, declares that 'the psalm lets us see the enthronement of Jesus at the right hand of God as the great theological reality of the Christological present.... It insists that the office of Jesus concerns nations and rulers'. It 'puts special emphasis on the command of Jesus to the church to make disciples of all nations'. ${ }^{55}$

54 Herbert W. Bateman thus prefers to describe the psalm as 'typological-prophetic' ('Psalm 110:1 and the New Testament', Bibliotheca Sacra 149 [1992]: 438-53 [453]). Brock, Singing the Ethos of God: 112, similarly speaks of 'a logical continuity bordering on synonymity between the terms "prophecy" and "prefiguring" in Augustine's interpretation of the Old Testament.

55 J. L. Mays, Psalms (Louisville: John Knox, 1994): 354-55. Postcolonial interpretation would note that linking Ps. 110 and Matt. 28:20 would provide useful support for the historical collocation of imperialism and mission. 
On the contrary, the text's inherent theological implications do not lie in its application to Jesus; that is to ignore its meaning. Its application to Jesus is part of New Testament study. For Old Testament theology, the question is, what did the Holy Spirit offer Old Testament believers in this text? ${ }^{56}$ The psalm declares that YHWH is on the side of the Israelite king and is involved in politics and history on that basis. YHWH uses the king in governing the nations, and acts in history with anger, energy, and violence. The king (and implicitly his people) is encouraged to live his life in light of ways YHWH has made this work out and in light of promises YHWH has made about how it will work out. In Israel's history that usually means believing against the odds.

Then, the particular distinctive motif of this psalm is that the king is also priest. There are things that are achieved by such combining of powers in one person. Politics and war are not allowed to escape from the context of the people's relationship with God, and the people's relationship with God is not allowed to escape from politics and war. These theological insights are unfashionable in the context of modernity and postmodernity in which Western Christians work out what they reckon is a Christian view on such topics. That Christian view often corresponds to the secular view; there is nothing very Christian about it. Interpreting the psalm in light of its use in the New Testament enables readers to neutralise its insights.

The idea of YHWH being on the Israelite king's side against Israel's enemies does have to be set in the context of the psalm's presupposition that the enemies are resistant to YHWH's purpose and that Israel is committed to it. But canonical interpretation must mean letting different parts of scripture have their say, not silencing some by others that we prefer. God really was speaking and acting in Old Testament times and therefore we should not let what God subsequently said and did overshadow what God was then saying and doing. Canonisation can encourage readers to flatten the meaning of the texts in the canon, to reinterpret the different books so that they form a harmonious whole that agrees with the views of people who recognise the canon. ${ }^{57}$ This temptation is to be resisted. (I sometimes think that in my students' eyes, their professor's job is to reassure them

56 Notwithstanding his concern for seeing Old Testament texts in light of their use in the New Testament, Childs makes this point in a study of Psalm 8 in the context of the Christian canon in Biblical Theology in Crisis: 162-63.

57 Cf. Halbertal, People of the Book: 23-24. 
that scripture does not say anything that does not fit what they already think. People of liberal Christian views do not need this reassurance; they can simply reckon that scripture is wrong. Evangelicals cannot do that, so they have to change scripture's meaning, to reach the same end of being able to continue to think what they have always thought.)

There is a thematic as well as a textual aspect to the way the New Testament reinterprets the Old Testament. The New Testament takes Old Testament themes and uses them as metaphors for what Christ does. Through the prophets, YHWH made various promises to Israel. In large part, these are reaffirmations of fundamental promises going back to Abraham, promises of receiving a land, becoming a flourishing people, and being a means of blessing for the world. As a result of Israel's desire for human kings and of David's desire for a fixed sanctuary, two further divine commitments get added to those original ones. The promises that appear in books such as Isaiah, Jeremiah, and Ezekiel are then substantially reaffirmations of those five fundamental promises of land, peoplehood, blessing, sanctuary, and monarchy.

The New Testament takes those promises and reworks them in expounding what Christ achieves. He is not literally Israel's anointed king, but he is that metaphorically. He is not literally a temple and neither is the church, but metaphorically his body is a temple and metaphorically the Corinthian church is God's temple. Christ is not literally a priest and his death is not literally a sacrifice, but metaphorically that is so.

To speak in terms of metaphor is not to imply that there is something unreal or artificial or untrue about what is said. Using metaphor is crucial to understanding the real significance of things, particularly new things. So when God becomes incarnate in Christ and when the incarnate one lets himself be crucified and when God becomes a reality in the life of a Gentile community such as the Corinthian church, metaphor enables the church to understand the significance of these new and unfamiliar realities by looking at them in light of realities they are already familiar with. This is the way the Holy Spirit inspires the church's understanding of Christ's significance.

But this metaphorical use of Old Testament motifs does not undo the reality of the Holy Spirit's inspiration of the original Old Testament promises, and that is the subject of Old Testament theology. When God made promises to Abraham about land, nationhood, and a ministry of blessing, and then made promises to David about monarchy and 
temple, this indicated that all these realities are important in their own right.

Peter Stuhlmacher urges a biblical theology of the New Testament that involves looking at the message of the New Testament in light of the Old Testament, ${ }^{58}$ but he does not suggest that this will do as Old Testament theology or as biblical theology (period). The biggest significance of the work of Walter Brueggemann is that he takes the whole canon with the utmost seriousness. He is not fond of talk in terms of scriptural authority or of the canon and he can read his own priorities into texts like the rest of us, but he shows a relentless insistence on trying to listen to every text rather than ignoring it or silencing it by means of other texts. In other words, he is an Old Testament theologian who works in light of the canon, and who treats the first part of the canon as significant in its own right. 'Old Testament theological articulation does not conform to established church faith' and therefore the responsibility of Christian Old Testament theology is 'to present to the ecclesial community not only those readings that confirm church theology, but also (and perhaps especially) those that clash with, challenge, and undermine seemingly settled church theology'. 59

\section{Old Testament Theology Expects to Find the Two Parts of the Canon Illumine Each Other}

My sixth point is a converse of that declaration that the canonicity of the Old Testament means it must not be subsumed under the New Testament. Thinking in terms of Old Testament theology does imply that Old Testament faith and New Testament faith are variants on the same reality, and therefore Old Testament theology expects to find that the two parts of the canon illumine each other.

Whereas the expressions 'The Torah, the Prophets, and the Writings' and 'the Hebrew Bible' imply (or can imply) that these collections of scriptures stand on their own, the expression 'Old Testament' (like my preferred expression 'First Testament')

58 See, e.g., Peter Stuhlmacher, How to Do Biblical Theology (Allison Park, PA: Pickwick, 1995).

59 Walter Brueggemann, Theology of the Old Testament (Minneapolis: Fortress, 1997): 107 (the first quotation is italicised). 
presupposes that these scriptures are part of a larger canon. Doing Old Testament theology in light of the canon means seeing the Old Testament as part of that larger canon. Old Testament and New Testament speak in similar terms of God and of God's activity in the world. They are a two-part DVD portraying the same person in different situations and from different angles, not two different persons.

It is a common Christian assumption that there is a contrast between Old Testament and New Testament. The Old Testament God is a God of wrath, the New Testament God is a God of love. The Old Testament teaches salvation by works, the New Testament salvation by grace. I will come back to the first of those misapprehensions, after commenting on the second in light of some observations by Paul. At the end of his preliminary exposition of his gospel in Romans $1-3$, he has to face the question whether what he has argued is biblical. Does it fit the scriptures? He knows that if he cannot establish this, his claims about his gospel collapse. If it is unscriptural, it cannot be true. So the question is, 'What does the scripture say?' (Rom. 4:3). He then shows that God established a relationship with Abraham on the basis of God's grace and Abraham's response of trust. This relationship became a reality before and independently of Abraham's observing the rite of circumcision, and a fortiori before God gave Israel the gift of other aspects of its religious life such as Exodus-Deuteronomy prescribe. ${ }^{60}$

This argument was the result of a hermeneutical process whereby something that happened to Paul suggested a new insight on the relationship between God and Israel, which led Paul to reread the scriptures to try to make sense of his new insight. He now saw the significance of an aspect of the Torah, the narrative sequence of Genesis $12-15$ and Genesis 17 and the Sinai story, which he had not seen before.

His argument seems exegetically sound. He thus illustrates the way a new experience or act of God or question can indeed open up exegetical understanding. The relationship between exegesis and appropriation is a two-way, conversational one, not a one-way movement whereby we first do exegesis and then do application. Reading the Old Testament in light of the gospel (in light of the New Testament, to be anachronistic) turns out to illumine the Old

60 This response of trust indeed issues in a life of obedience, as Gen. 22:18; 26:5 observe (and cf. James 2:21-24), but I do not think this affects Paul's point. 
Testament. While such reading can involve finding in the Old Testament a significance that in itself it does not have, in this case Paul does not rework the significance of the Old Testament; he enables one to read the Old Testament with more exegetical acumen. In theory, one might achieve this insight without the help of the Christ event. But the Christ event actually was the ultimate outworking (as opposed to reworking) of the way God dealt with Abraham, so it is not surprising that it helps to clarify the Abraham story's intrinsic nature.

Something similar is true regarding the God of wrath and the God of love. In Christ God submitted to crucifixion by humanity and then came back to a renewed life, declining to let even humanity's execution overwhelm God's desire to be in relationship with humanity. God thus paid the price for humanity's sinfulness, made the sacrifice that dealt with that $\sin$.

Did this mean the God of wrath had become the God of love, with that changeableness that Jack Miles traces within the Old Testament? ${ }^{61}$ The New Testament does not think this way. Or had God always been the God of love, but had concealed this through Old Testament times because of a commitment to progressive revelation? The New Testament also does not think this way. It rather sees what God did in Christ as the logical culmination to the Old Testament story. The cross then makes one look back at the Old Testament to look for the footsteps of the crucified God there. And one sees them. In light of where the story of God and the world reaches its climax, one can read the earlier part of the story more clearly, and see more clearly the significance of some of the scriptural comments on it.

In the Old Testament God does from time to time act in wrath in relation to the world and to Israel, but these acts appear in the context of a story that begins and continues only because God acts in love. If the Old Testament God were essentially wrathful, the Noah flood would be a model for the way God relates to the world rather than a one-off event whose theological significance is precisely the fact that God has looked in the eye the logical possibility and moral appropriateness of destroying the world and has affirmed a commitment not to do so, precisely 'because the planning of humanity's heart is evil from its youth' (Gen. 8:21). ${ }^{62}$ The story of

61 See Miles, God: A Biography.

62 No 'even though' this is so (TNIV); the preposition is $k \hat{\imath}$. 
humanity and of Israel continues despite their waywardness because commitment (hesed, the Hebrew equivalent to agape) not wrath is the dominant principle on which God works. Like a father or mother in relation to their children, God 'carries' Israel's sin (nāśa' ; the conventional translation 'forgives' obscures the idea). Instead of making Israel carry it, bear responsibility for it, God does so-not in the sense of accepting responsibility for the sin happening but in the sense of accepting responsibility for dealing with it, for the consequences of it. If I wrong my wife, I might expect to pay the price; she might walk out on me. When Israel wronged God, God paid the price; God did not walk out on Israel. At least, God never definitively did that; God might storm out for a while, but always came back. Karl Barth puts it like this. The incarnation and the cross involve Christ in going into the far country, like the Prodigal Son, in taking the form of sinful humanity. But 'the God of the Old Testament... is already on the way into the far country to the extent that it is an unfaithful people to whom He gives and maintains His faithfulness'. ${ }^{63}$

Love is nearer the heart of God than wrath or judgment. God first expresses the point at Sinai in that self-description that explains how it is that YHWH stays with Israel despite its rebellion. YHWH is characterised by compassion, grace, long-temperedness, commitment, steadfastness, a willingness to carry waywardness, rebellion, and failure, and by not remitting punishment (Exod. 34:6-7). The selfdescription does not clarify the relationship between the long list of 'positive' characteristics and the footnote describing the 'negative' ones. ${ }^{64}$ Other Old Testament passages do so. Isaiah 28:21 describes punishing Israel as 'strange' or 'foreign' to YHWH. YHWH does it, but it does not come naturally. Hosea 11 describes YHWH as contemplating acting in wrath but resisting the inclination to do so; it is precisely because of being the holy one that YHWH will not act in wrath. Lamentations 3:33 declares that when YHWH afflicts or grieves

63 Karl Barth, Church Dogmatics IV/1 (reprinted Edinburgh: Clark, 1961): 171. Barth goes on (279) to describe Israel's history as 'one great series of dark and heavy judgments on the part of God', so that 'Israel is a people which is constantly judged by God'. After its arrival in the land, are there any such dark and heavy judgments apart from the fall of Ephraim and the fall of Judah? (Even in Judges, trouble affects only individual clans or groups of clans.) Perhaps one gets that impression because the prophets issue many dark and heavy warnings of judgment, but it is those two events that are the chief fulfilment of them all.

64 Translations help it along: see, e.g., the 'yet' in NRSV, TNIV, and NJPS. 
people, it is not 'from the heart' (translations have 'not willingly'). YHWH is capable of acting in wrath and does do so, but it is not as 'natural' to YHWH as acting in compassion and mercy. Justice and love are not equally balanced in God.

The God who is inclined to carry human waywardness, who is characterised by compassion, who is prepared to act in judgment but prefers to avoid doing so, is exactly the God who submits to crucifixion by people and thus pays the price for their waywardness with the aim of keeping in relationship with them (though if they insist on holding onto responsibility for their waywardness, they may do so). Looking back at the Old Testament from the New Testament makes it possible to see the pattern in these aspects of the way YHWH acts and speaks, and the way people speak about YHWH, which we might otherwise miss.

It is the New Testament that may help us see that in the Old Testament, but it is something that is actually there, something one can ask any interpreter to see. In principle it should be the case that Jews and Christians (and atheists or agnostics, Jewish or Gentile) interpret the Old Testament in the same way, even when they are talking about the theological implications of the text. We do not interpret canonical texts by means of different methods from ones we use for other texts, methods that involve bringing something from outside that gives us an interpretation no one else could possibly reach. I do not use a different approach for interpreting Ecclesiasticus and Proverbs, or for Judith and Esther, or for Psalms 151-55 and for Psalm 1-150. I have special expectations in reading Proverbs, Esther, and Psalms 1-150, and a commitment to being open to whatever I find there. ${ }^{65}$ But the process of discovering what is there is not different. Rolf Rendtorff observes, 'the Hebrew Bible is itself a theological book.... The Bible does not become theological through interpretation through a later-elaborated theology, be it rabbinic or Christian; rather, it is possible and necessary

65 Indeed, 'the proper reading of Scripture depends on a repentant self-effacement before the converting power of God and his Word'. Thus the problem about reading scripture is not technical but spiritual and moral: 'we refuse as sinners to be spoken to... and desire to live from our own word' (Brock, Singing the Ethos of God: 63, 64, summarising John Webster, Word and Church [Edinburgh: Clark, 2001]: 96-97, summarising Karl Barth and Dietrich Bonhoeffer. I am not sure whether this is the kind of thing that John Sailhamer means by a sacred hermeneutic, different from the hermeneutic one applies to other texts (Introduction to Old Testament Theology: A Canonical Approach [Grand Rapids: Zondervan, 1995]: 227-37). 
to find the theological ideas and messages of the biblical texts themselves.' 66

The whole Old Testament 'is God-breathed and useful for teaching, for rebuke, for correction, for training in righteousness, so that anyone who belongs to God may be ready, made ready for every good work' (2 Tim. 3:16). God grant that Old Testament theology done in light of the canon may contribute to that.

66 Rolf Rendtorff, Canon and Theology (Minneapolis: Fortress, 1993): 40-41. 